\title{
GERMINATION OF SPRUCE AND FIR SEED FOLLOWING DIFFERENT STRATIFICATION PERIODS
}

\author{
By H. G. MacGILLIVRAY ${ }^{1}$
}

Germination tests were made of white, red, and black spruce (Picea glauca (Moench) Voss; P. rubens Sarg.; and P. mariana (Mill.) BSP) and balsam fir (Abies balsamea (L.) Mill.) seeds that had been stratified for different periods of time. The seeds were wrapped in newsprint in lots of 50 and stored in jars of moist sand. These jars were kept in a refrigerator in which temperatures varied from $32^{\circ} \mathrm{F}$. to $38^{\circ} \mathrm{F}$. The germination tests were made in sandflats. Each sandflat was divided into eight compartments. Generally, for each species two replications of 50 seeds were sown in each sandflat. Species were allocated to compartments at random. The germination tests were based on the germination which occurred during the first 30 -day period after sowing. The size of the samples varied (Table 1).

TABLE 1

Percentage Germination

\begin{tabular}{|c|c|c|c|}
\hline $\begin{array}{l}\text { Months of } \\
\text { stratification }\end{array}$ & $\begin{array}{c}3 \text { months } \\
\%\end{array}$ & $\begin{array}{l}14 \text { months } \\
\%\end{array}$ & $\begin{array}{c}27 \text { months } \\
\%\end{array}$ \\
\hline White spruce & $82(400)$ & $75(400)$ & $(-1)$ \\
\hline Red spruce & $66 \quad(400)$ & $45 \quad(400)$ & $10 \quad(200)$ \\
\hline Black spruce & $76^{1}(400)$ & $50^{1}(400)$ & $11(150)$ \\
\hline Balsam fir & $42 \quad(400)$ & $50 \quad(200)$ & $0.5 \quad(200)$ \\
\hline
\end{tabular}

Note: The number of seeds used in each test is shown in brackets.

${ }^{1}$ A t-test indicated that the difference between the average values for these tests was significant at the one per cent level.

Surprisingly small differences in germination occurred within each species between the seeds stratified for three months and those stratified for 14 months (Table 1). In this comparison, black spruce was the only seed showing a significant decrease in germination after having been stratified for 14 months. Although some individual seeds may retain their viability after stratification for 27 months, severe loss of viability may be expected in seedlots that have been treated for this length of time.

These results indicate that seedlots which are not sown during the first spring after initiation of stratification may still germinate well if they are sown during the second spring. Some seedlings may be expected from seedlots that are not sown until the third spring after initiation of stratification, although severe loss in viability in such seedlots should be expected.

The only situation where this treatment is apt to be duplicated in nature is in cold sphagnum bogs. One may infer that a few spruce and fir seeds will remain viable after two or three years of storage in the bog floor.

\footnotetext{
${ }^{1}$ Research Forcster, Forestry Branch, Maritimes District Office, Fredericton, N.B.
} 